\title{
Insuring the Charge Claim According to the Kosovo Law on Contested Procedure
}

\author{
Rrustem Qehaja \\ Professor of Civil Procedural Law and Insurance, Law at University of Prishtina. PhD.
}

\author{
Doi:10.5901/ajis.2015.v4n1s2p173
}

\begin{abstract}
This article analyzes insuring the charge claim in context of the Law on Contested Procedure, although this issue in the past has been regulated with the Law on Enforcement Procedure. This new regulation has brought many dilemmas in the judicial practice, and so far one of the goals of this paper will be focusing in these dilemmas and also giving recommendation in order to overcoming them. This legal institute will be analyzed in term of legal theory and judicial practice
\end{abstract}

Keywords: Civil Procedure, Civil Contested Procedure, Lawsuit, Lawsuit Insurance, Kosovo Law on Contested Procedure.

\section{Introduction}

By insuring the lawsuit claim, we mean ensuring any rights in order to come to the materialization of subjective rights of its holder. Usually the mandatory materialization of subjective rights is necessary in order that the owner to be authorized by judgment or any other executive document. The judgment or executive document ${ }^{1}$ the right holder must materialize of acquire within the contested procedure or any other procedure provided for by law. From the initiation of this procedure to its completion, usually takes a long time, especially considering that against the decisions of first instance ordinary legal remedies are allowed - appeal2 ${ }^{2}$, so from the completion of the procedure to its final form it can pass relatively long time and during the time between there is a possibility that circumstances change based on which the holder of the right would face difficulties in materialization of his/her rights.

The possibility of changing circumstances in the materialization of the claim before the court judgment or other type of executable document becomes executable, regardless whether the claim has to do with money or non-monetary demands, it lies in that the debtor can dispose of movable or immovable property, in order to create the circumstances to make execution impossible. For this reason, different sets of rules are foreseen to give the creditor the opportunity to secure his claims. ${ }^{3}$ These rules are set forth in the Law on Contested Procedure. Therefore, the proceedings would be incomplete if there are no provisions which will be available to the authorized party to request the insurance of the execution of his claims through the end of the regular judicial procedure. ${ }^{4}$

Up to the adoption of the Law on Contested Procedure of 2008, the Law on Executive Procedure provided for respective legal provisions and these were according to the insurance measures: 1 . the right of pledge on real estate, 2. preliminary measures and 3. provisional measures ${ }^{5}$. Whereas, the provisions of LCP 1977 provided only provisional measures where the court during the trial, on the proposal of parties or "ex officio" has ordered such measures until the end of the final dispute and no special appeal was allowed against this decision. ${ }^{6}$

Peculiarities of the measures provided for by LCP (Yugoslavia 1978), were that the two measures before as the pledge on real estate and preliminary measures, besides general conditions that had to be met, such measures could be defined only when the creditor's request was confirmed by the court judgment which yet was not become final or executable, whereas the provisional measure was not limited to the existence of the court judgment, so it was possible to be submitted before, during and after completion of the trial on the dispute.

In addition to, in order certain provisional measure to be ordered, the law does not necessarily anticipate the

\footnotetext{
${ }^{1}$ Law on Contested Procedure of Kosovo (LCP) no. 04/L-139 date 20.12.2012, Article 22

2 Rrustem Qehaja "Appeal against judgment in the civil-contested procedure", Law life no. 1, March 2013, Tirana 2013 , page 4.

3 Iset Morina \& Selim Nikçi, Commentary of the Law on Contested Procedure, Pristina, 2012. Page 541.

${ }^{4}$ Boris Pozniq, Law Commentary on Civil Procedure, Beograd, page 578

${ }^{5}$ B. Pozniq, Commentary cited page 578 and Law on Executive Procedure (LEP), OG of FRY no. 20/1978, Article 245.

${ }^{6}$ Law on Contested Procedure (LCP), OG of FRY no.4/1977, Article 442.
} 
amount of insurance, but this insurance as named by law "bail" court orders it on basis of circumstances and when on debtor's proposal may oblige the creditor to deposit the bail amount as a condition of ordering provisional measure. In cases where the creditor has not made credible the existence of the claim and risk, the court may order a provisional measure on the creditor's proposal for deposition of the bail for the damage that could have been caused to the debtor. ${ }^{7}$

Whereas, with the adoption of the Law on Contested Procedure in 2008, all provisions relating to the provision of lawsuit are included in Chapter XXI, Article 296 through Article 318.

\section{Conditions and Measures of Lawsuit Insurance}

Insurance measures of the lawsuit do not prejudice the main dispute, but they only serve to securing the claim or rights that are subject to dispute. Therefore, insurance measures do not secure satisfactorily the plaintiff's request i.e., the measures do not replace the judgment but they are means to secure factual and legal status (to protect the status quo). ${ }^{8}$ Based on this, insurance measures can not be ordered to the extent that solve the claim, because in the opposite the enforcement of insurance measure would mean the final execution of the judgment. ${ }^{9}$ Therefore, even with the provision of Article 300.3 of the LCP it is foreseen that insurance measures should not cover entirely the claim suit secured by them.

Insurance measures can be determined if the following conditions:

If the propose of the insurance makes it believable the existence of the request or of his subjective, and in case there is a danger that without determining a measure of the kind the opposing party will make it impossible or make it difficult the implementation of the request, especially with alienating of its estate, hiding it, or other way through which it will change the existing situation of goods, or in another way will negatively impact on the rights of the insurance party that proposed. If it's not determined differently by law, the court will determine the measures of insurance within the set deadline by the court as it is determined by the Law for the final procedure, it will issue guaranties on the measure and the type specified by the court for the damage that can be caused to the opposing party by determining and executing the insurance measures. ${ }^{10}$

While proponent, respectively the plaintiff, can justify the claim, by augmenting it with probative means and the risk that the opposing party will not allow the materialization of the claim can justify it on the basis of objective reasons depending from case to case. The threshold, as a third condition to allow insurance measures, usually is paid in cash (in Euros since this is the official currency used in Kosovo), but the court may also allow the this insurance be in the form of bank guarantee, securities ${ }^{11}$, as well as valuable items, whose value is easily determined in the market which can quickly and easily be converted into cash. ${ }^{12}$

The amount of the guarantee is determined by the court based on circumstances of each individual case and taking into account the damage that may be caused to the insurance opponent with ordering and execution of insurance measures and it orders this amount based on common sense evaluation, since the law does not set any specific criteria for the amount of the insurance.

A criterion for determining the amount of the insurance can be that the more credible the claim of the plaintiff is or specifically the smaller the amount is or in contrary, the less reliable be the lawsuit of the plaintiff is this should be the amount of the insurance..$^{13}$ According to a practice that has been applied by international judges, the amount of such insurance is set from $5 \%$ to $30 \%$ of the lawsuit. ${ }^{14}$

This amount, deposited by insurance proponent, shall be refunded by court order to the proponent within 7 days from the date when insurance cases to exist, and if the opposing party files a lawsuit against the proponent of the insurance for damage compensation caused by ordering of security measure then the competent court shall decide on

\footnotetext{
${ }^{7}$ LCP of FRY, Article 270.

${ }^{8}$ Presentation on Insurance Measures by EULEX judge, Pristina, on 27.04.2012

${ }_{9} \mathrm{~B}$. Pozniq, works cited page 583

${ }_{10}$ LCP of Republic of Kosovo No.03/L-2006 dt.30.06.2008, Article 297 and group of authors "Law Commentaries of the Civil Law Procedure of Bosnia and Herzegovina Federation and Republic Serpska", Sarajevo 2005, page 442

${ }^{11}$ Regulation of the Central Bank of Kosovo (CBK) on the Primary and Secondary Markets for issuance of Government Securities 16.12.2011 and the Law on Executive Procedure Article 2 paragraph 1.15

12 LCP Article 297.2

${ }_{13}$ Presentation by EULEX judge on insurance measures, Pristina on 27.04.2012, page 7

${ }^{14}$ Cited works page 7
} 
this lawsuit through a trial about this damage also may decide to uphold the security measure or determine the amount of the guarantee not to be refunded to the proponent of insurance until the end of the trial according to the claim for compensation. ${ }^{15}$ This period of 7 days is too short for the respondent if he/she decides to initiate compensation proceedings, so we think that in the amendments to this law this term will be longer and not shorter than 30 days, in order for the respondent to prepare for initiation of compensation procedure.

The lawmaker, out of an obligation to deposit the insurance, has excluded the units of local governance. ${ }^{16}$ We believe that this provision is unclear and perhaps a mistake taken from the previous law ${ }^{17}$, because the units of local governance can propose such measures which can cause damage to the opposing party and that there is no reason these are released from this obligation.

On the other hand, if the party is unable to pay the security without jeopardizing his family situation, at his request the court may waive this obligation. ${ }^{18}$ In this case, if the party offers credible evidence for this, the court with a special ruling decides on the request for exemption from this guarantee.

\section{Types of Lawsuit Insurance Measures}

Depending on subjective right, the owner of which claims to have it, the following lawsuit insurance measures can be ordered:

* Insurance measures for insuring monetary claims,

* Measures for insuring claims at the directed item or at part of it, which otherwise called security measures for providing non-monetary demand and

* Measures for insuring their rights or preserving existing circumstances. ${ }^{19}$

For each of the above three types of lawsuit insurance measures are provided sub types of insurance that correspond to the lawsuit insurance object, whether relating money demands or non-monetary demands as well as for the preservation of rights or existing situation.

These measures are set forth under the current LCP. Unlike this law, the LCP of 1978 that used to regulate the insurance measures provided these measures as in the following: right of pledge on real estate, preliminary measures and provisional measures. Depending on the type of measure, provided the specific conditions for allowing these measures. As noted above the current LCP has not made any strict separation of these measures in the name, as did the old LCP, because the legislature had considered that all measures taken by the court in order to claim insurance in last instance, nevertheless they present insurance measures, which can be of different nature, because they depend on individual cases and specific relationship, but their ultimate goal is the same.20

\subsection{Measures to insure monetary demands}

For insuring money requests, these measures can be ordered:

a) Banning the opponent of the insurance from alienating, hiding, indebting or holding a wealth set for the sufficient amount for securing the request of the party that proposed. This restriction will be registered in the public record.

b) Safeguarding of a wealth related to the restriction from the above point from the court in its provisions. When possible or when given in the possession of the party that proposed the insurance or third party;

c) Banning the debtor of the insurance opponent so the latter will have his request fulfilled or hand over the good, as well as stopping the opponent of the insurance to accept the good, to implement the request or own it;

d) Pre-notification of the right of pledge over the real estate of the opponent of the insurance, or on the registered right for the real estate, an item in the value of the main request, with interest and procedural spending for which was rendered a decision which is not yet executable. ${ }^{21}$

\footnotetext{
${ }^{15}$ LCP of the Republic of Kosovo No.03/L-2006 dt.30.06.2008, Article 298

${ }^{16}$ LCP 2008 Article 297.4

17 Presentation by EULEX judge on insurance measures, Pristina on 27.04.2012, page 7

${ }^{18}$ LCP No.03/L-2006_30.06.2008, Article 297.3

${ }^{19}$ LCP 2008 Article 299, 300 dhe 301

20 I. Morina and S. Nikçi, Cited Commentary page 541.

${ }^{21}$ LCP-No.03/L-2006 dt.30.06.2008, Article 299.
} 
Measure under a), means that insurance opponent can not sell, donate or hide or in any other form dispose of and to alienate the pledge, mortgage or any other obligation, his wealth to the value of the claim of the proponent, including interest and costs of proceedings. Every action of the insurance opponent, who acts contrary to such measure is invalid but there is an exception to this principle, and that when the third person has acquired any right over the property of the opponent under the provisions of material law, i.e. when there is room for the application of the rules for the protection of bona fide beneficiaries. Moreover, this decision will officially be sent to the respective public registry to prevent any change in these registers.

Measure under $b$ ), means that items that are subject to the measure will be stored in court if the latter is likely to do so or be entrusted for safeguarding to the proponent or the third person. These items should not be used so either by a third person, nor the sponsors but neither the court, if entrusted for safeguarding.

Characteristics of the above measures, especially of that in point a) and b) are that the on the proposal of the insurance opponent or guardians (who may be the court, the proposed insurance or third person), the court may decide to sell movable items for which there is a danger that can easily and quickly damage or if there is a risk that the value of these items will drop significantly. The sale of such items must be done according to the rules set under the executive procedure for movable property. ${ }^{22}$

The sale of such items is done through the verbal public auction, or through direct settlement between the purchaser, in one side and the official person, or other authorized subject in other side or other authorized party. The manner of sale of items is determined through court conclusion, bearing in mind the fact achieve the most suitable price for respective items. ${ }^{23}$ The amount of money gained from the sale of movable goods or through the implementation of the loan is preserved in the court deposit up to the moment of removal of the measures of security or up to the moment when its execution is proposed but at the latest within a period of thirty (30) days from the day the loan has arrived. Other goods gained by requested loan are deposited, if possible they are deposited in the courts deposit, or there are other means of savings until the moment of removal of the security measures, respectively until the party proposing security will propose an execution but at the latest thirty (30) days from the day when the loan becomes exceptional. ${ }^{24}$

Of course, that in these cases the question is what will happen to the money deposited or even items found with the custodian. We think, if the insurance proponent wins the dispute or the executive ownership in a regular court procedure, then right over these items will be materialized through executive procedure, and certainly, those things that found with the custodian shall be handed over to the proponent (plaintiff, creditor). As if these items are sold and the money is in the court, in this case on insurance proponent's will materialize his claim from the money deposited.

Measures under c) contain in fact two requirements, one has to do with banning the debtor of the insurance opponent to meet the demand or to deliver certain items and ban insurance opponent to accept the good, to implement demand or dispose of it. These situations arise when insurance opponent is in civil-legal relationship with a third person. By this insurance measure, the court will prohibit to third person as long as the measure lasts not to pay the amount of money that he owes to the insurance opponent or deliver a certain item, where would hamper a execution of the proponent's request. In case the third person acts against the order of the court, he will be responsible for eventual damages. Third person may deposit his obligation he has towards the proponent in court or to the person assigned by court as a custodian. With this, the third person is released from this responsibility. ${ }^{25}$

Measure under d) or notification on non-possessory pledge ${ }^{26}$ means registration in public real estate registry, of this nature and only after the final judgment was rendered, according to which the rights of the proponent are recognized, but has not yet become executable. As seen, this measure is one of the strongest measures that ensures monetary demands of the insurance proponent, as well as its setting conditions are stronger because as a condition for this a judgment must exit.

We believe that the condition for the ordering of this measure "judgment" that is not yet executable, is a technical error that should be replaced with executable document because its proponent's monetary demand can prove it with a judgment or an administrative act. Also the old LEP provided a condition that for allowing this measure the creditor must argument this theough an executive document, which in addition to the judgment it also includes administrative decisions.

22 LCP 2008 Article 311

${ }^{23}$ LEP of Republic of Kosovo No.03/L-008, 02.06.2008, Article 91 and 92.

24 LCP of Kosovo No.03/L-2006, 30.06.2008, Article 311.4

25 I. Morina and S. Nikçi, cited commentary page 548.

${ }^{26}$ Law on Property and other Real Estate Rights no. 03/L-154, 25.06.2009, Article 162 


\subsection{Insurance measures for non-monetary demands}

For insurance of non-monetary demands or insurance directed to certain item or part of it, the following measures can be applied:

a) Banning the opponent of the insurance to alienate, hide, indebt or holding the wealth on which the request was directed. The forbidding will be registered in the respective public real estate record.

b) Safeguarding of the wealth referring to the proponent's demand, by depositing in court, or if that is possible, hand over to the proponent of the insurance or the third person,

c) Banning the opponent of the insurance to commit act, which could damage the part of the wealth toward which the request was sent, or the order against the objector of the insurance to conduct action for protecting the wealth, and protecting the existing situation of the goods,

d) Authorization of the party that proposed the insurance to carry out specific activities.

Two of the first measures under a) and b), are the same as the insurance measures on the execution of monetary demands. The difference lies in the way that these measures, in monetary demands insurance, the proponent will execute his demand from the sale of these items to which the measure is ordered, whereas in the insurance measures for execution of non-monetary demands, the proponent directs his claim specifically on those items he claims are his stuff.

Whereas the measures provided for in paragraph c) and d) differ from the measures foreseen in the part of insurance of monetary demands. The measure provided for in paragraph c) of this section contains two separate obligations for insurance opponent, which are independent of one another or rather saying contain two sub-measures. One has to do with banning the opponent of the insurance form any action that might lead to damage of property directed at the request of the proponent and the other has to do with the directive to insurance opponent to perform certain actions necessary to maintain object property or to maintain existing condition circumstances. Therefore, to that extent we have two situations, one where the insurance opponent is requested not to act and another situation where he is requested to act. $^{27}$

As regards to point d), which deals with the authorization of the proponent to perform certain actions or necessary to the item or property of the insurance opponent, the court may authorize when necessary to preserve the status quo or any obstruction causing damage. These authorizations may be different and depend from case to case or by legal and civil relationship that exists between the proponents and opponents of insurance. Thus, for example, the court may authorize the proponent to utilize the right of use of immovable property of the insurance opponent, until decided regarding the claim for verification of servitude respectively for the right of use.

Characteristic of measures to insurance of non-monetary demands directed on certain items or a part of it is that these measures should not include entirely the claim over which insurance exists. ${ }^{28}$ From this paragraph we can not understand what the purpose of the legislator has been and what goal can be achieved and thus we think that during the drafting of the law is made a mistake because there is nothing wrong with the proponent's measure directed at certain item or part of it to be included as a whole claim of the proponent, because the purpose of it is that he at the end of the procedure can execute his whole claim.

\subsection{Insurance measures on rights or preserving existing condition}

For insuring rights or preserving existing circumstances, the lawmaker has foreseen these measures:

a) Banning of the insurance opponent to perform specific activities aimed at preserving existing situation or not allowing damaging the opposing party;

b) Authorization of the insurance proponent to conduct specific activities;

c) Leaving the wealth of the insurance opponent for custody or care to the third party;

d) Other measures set by the court as necessary for lawsuit insurance. ${ }^{29}$

The above measures relating movable property, which can destroy easily and quickly and if there is a risk of their price fall, the court on the proposal of the opponent or custodian of these items can decide to sell these items under the

\footnotetext{
27 I. Morina and S. Nikçi, cited commentary page 551

${ }^{28}$ LCP of Kosovo No.03/L-2006 dt.30.06.2008, Article 300

29 LCP 2008, Article 301
} 
rules of execution procedure and the money acquired out of sale be deposited at the court depositing account.

As seen from the above mentioned types of measures for insurance of rights or preserving the existing circumstances are similar to other measures for securing monetary demands and non-monetary demands except the last measure or better saying point d) of this Article and that at this point this was left to the court discretion to decide and determine any other measure that is necessary to secure the proponent's lawsuit.

\section{Content of the Proposal for Ordering the Lawsuit Insurance Measures}

The proposal for ordering measures for lawsuit insurance in principle are submitted in writing, but they may also be presented orally during an ongoing trial at the stage of reviewing the lawsuit/claim respectively. Therefore, the proposal may be submitted at any stage of the proceedings, in the first instance through the completion of the main trial, but it can also be submitted in the proceedings of the second instance, when the case is at the court deciding on the appeal.

When the proposal is submitted in writing same as submissions should contain every detail that is needed to act accordingly, thus must contain the introductory part, the claim to be insured and signature of the proponent. In the introductory part of the proposal should be identification of the litigants, the object of dispute, the amount in dispute whereas in the part of the content should be described the claim to be secured the object and means of the security measure, the facts on which the claim is grounded and evidence which support such fact. ${ }^{30}$ If possible, the proponent shall attach to the proposal the evidence that supports the claim, and which make it credible for imposing the insurance measure as well as those that justify the risk that without insurance measures the opponent will make it impossible or difficult to have subjective execution.

Also, the proposal should contain such information even when the proposal is presented orally at the hearing, with the exception of the facts and evidence to prove such facts that relate to the reliability of the claim, because these data are in the body of the lawsuit itself contained, according to which the judicial subject matter is being processed. ${ }^{31}$ Proposal for insurance measures may be presented verbally before the competent court even before the initiation of court proceedings by lawsuit; in this case, the above provisions should be applied accordingly. ${ }^{32}$

If the proposal does not contain all the necessary data provided by law, the court in this case will act as the complaints is irregular and incomplete and will return the same proposal to the proponent for amendment and correction. If the proponent does not act according to the instructions of the court, shall be considered that the proposal is withdrawn. In case the submission is corrected by the deadline set by the court, which is three days, and sent to the Court then it will be deemed to be submitted within the first legal deadline, thus the court will reject the proposal. ${ }^{33}$

So, the proposal for ordering insurance measures should contain all the necessary data which were mentioned in the above paragraphs, and it must be noted that the most important among them is the object of the claim, which means the item or the right on which the insurance measure is imposed. When the proponent proposes any insurance measure he shall in the proposal describe the type of request and depending on the type of request may propose any of the measures provided for securing monetary claim, or measures which are provided for insurance of non-monetary demands as well as those that are provided for securing the rights or preserving existing situation.

\section{Submission of the Insurance Proposal}

Insurance measures can be proposed before initiation of court proceedings, during its development, and after the trial, until the execution is completed in its entirety. If the court orders the insurance measure proposed by the proponent prior to the commencement of trial, the court should bind the proponent that in the term of 30 days, to initiate court proceedings by a lawsuit in order to legalize and justify the proposed measure and therefore should notify the court, respectively the judge who has given issued the insurance measure that he has acted according to this obligation. ${ }^{34}$ If the proponent does not initiate the judicial process by the deadline set by the court, then the court will terminate the procedure and will annul completed actions. ${ }^{35}$

\footnotetext{
30 Therein, Article 304

31 Therein, article 304.2

32 Therein, Article 304.4

${ }^{33}$ Ruling of the Municipal Court in Pristina C.no.1352/09, 22.09.2011.

${ }^{34}$ Ruling of the Municipal Court in Pristina C.nr.464/12, 08.03.2012.

${ }^{35}$ LCP of Kosovo No.03/L-2006, 30.06.2008, Article 308.
} 
So, this deadline as mentioned above is the term that the legislator has intended to produce effects, however wrongly in the Article 308.1 of LCP is written that this term will be no shorter than 30 days and it is believed that in the future with the amendment the law, this term will be corrected, and must be within 30 days. Thus, the same has been regulated by the old law too.

To decide on the proposal for ordering the lawsuit insurance measure before the lawsuit is filed ${ }^{36}$ and during judicial proceedings, competent to handle this is the court that handled the lawsuit, whereas on the proposal submitted after the completion proceedings, competent it is the court that decided on the execution of the decision. In addition, the proposal for insurance measure can be filed with the court of second instance, while the case is in procedure with the court deciding on the appeal. ${ }^{37}$

If in the meantime there is a need to change means and objects of insurance, insurance proponent may propose such amendment to the court within the same procedure and based on the same order, ${ }^{38}$ and in these cases it is not necessary that the insurance opponent is given a deadline for response, and if the proposal is grounded, the court with a decision will change the means and the object of insurance, even though these means will be secured the proponents' lawsuit.

\section{Court Jurisdiction to Decide on the Insurance Measure}

The notion jurisdiction in objective view of the work environment we mean the scope of activity of a body, whereas in subjective view, jurisdiction means the right and duty of a body to act in certain legal issue. ${ }^{39}$ Rules that define the range of powers of a body also set the jurisdiction ${ }^{40}$ of these bodies based on the type and nature of the dispute.

In legal systems in general but also our legal system in particular are created various bodies so that subjects of law are given legal protection associated with subjective rights that are prescribed by law. Such bodies are regular courts, special courts (Special Chamber of the Supreme Court) and administrative bodies. In order to respect the adversarial principle, a principle which is envisaged by the Constitution and the European Convention of Human Rights, according to which are created bodies of different instances. ${ }^{41}$

Court before which the proposal on insurance measure was submitted should firstly ascertain its jurisdiction (absolute jurisdiction), by other national or foreign bodies and ascertain case and territorial jurisdiction. Case jurisdiction determines the scope of courts of different kinds and the courts of the same type but different ranking, and the main criterion for setting this jurisdiction it is the subject of litigation. Whereas, territorial jurisdiction determines the competence of a body that can acts in a legal issue and is related to the territory where it conducts its activity.

If the court finds that the issue that was presented before it, namely the proposal for insurance measure, of which the claim relates to any other body or foreign country, then the proposal for insurance measure will be rejected as unfounded. 42 If about the legal issue is foreseen another real or territorial jurisdiction the court in this case will be declared incompetent regarding the real or territorial jurisdiction and after a final decision the case file will be forward to the competent court.

Provision of Article 296 of the LCP, that provides for the jurisdiction of the court of first instance is understandable, but the second paragraph of this provision is ambiguous and presents problems during practical implantation because it is not a complete legal provision regarding highest court jurisdiction when the proposal on insurance measure is submitted at the time when the case is sent to this court for decision-making.

The law also does not contain other provisions as regards to the composition of the court to rule on the amount of

\footnotetext{
${ }^{36}$ LCP 2008, Article 296

${ }^{37}$ Law Commentary on Civil Procedure of Bosnia and Herzegovina Federation and Republic Serpska (group of authors) Sarajevo 2005, page 463-464

38 LCP 2008, Article 307.2

39 Faik Brestovci "Civil procedure law I", Pristina 2008, page 51

${ }^{40} \mathrm{~F}$. Brestovci cited works page 39-40

${ }^{41}$ The Constitution of the Republic of Kosovo (approved on 08.04.2008, entered into force on 15.06.2008), Article 32 provides for "The Right to Legal Remedies", according to this article: Every person has the right to legal remedies against judicial and administrative decisions which affect his/her rights or interests in the way prescribed by law.

A right that is foreseen by the European Convention for the Protection of Human Rights and Freedoms, Article 13 of the Convention guarantees the right to an effective remedy before a national authority.

42 Ruling of the Municipal Court in Lipjan C.no.216/11, 22.08.2011.
} 
insurance, as it is known that the second instance court is consisted of judges in the panel composed of three professional judges. There is a question whether in the insurance measures shall decide an individual judge or panel of judges. As well as the question of who will decide on a legal remedies in cases where the court of second instance has issued insurance measure, when this court as second instance decided as the Supreme Court.

However, with the promulgation of the law on courts ${ }^{43}$ was foreseen a new organization of the courts in Kosovo ${ }^{44}$, where, according to this law there is a Supreme Court, Court of Appeals and the Basic Courts. According to this organization Supreme Court decides only on extraordinary legal remedies.

The Court of Appeal decided only to appeals from relating decisions of Basic Courts. Whereas, Basic Courts decide on all matters in the first instance. With this new organization of the judicial system, the Court of Appeal decides in the first instance, it is therefore excluded the possibility that the Supreme Court decides on security measures, because it will no longer decide as a second instance court.

However, it remains disputable when the Court of Appeal decides or issues the insurance measure when the case is before this court as a matter to be decided according to legal remedies. A question comes up about who will decide on the appeal against the decision with which this court issued the insurance measure. The Supreme Court does not have jurisdiction to decide on appeals against decisions of the Court of Appeal because this Court decides as stated above only for extraordinary legal remedies. In addition, the problem appears when in cases against decisions of the court of second instance no appeal is allowed, whereas pursuant to Article 310.1 of the LCP, a ruling based on which an insurance measure was ordered appeal is allowed. So, in this situation we consider that the legislator has not clearly regulated the subject matter, and we think it was supposed to regulate it by excluding the right to appeal when the court of second instance decides on the insurance measure, issues the measure. In this case the exclusion of the right of appeal would be in accordance with the principle, that against decisions of the court of second instance no appeal is allowed, and the fact that there is no such body that will decide on the right of appeal because Supreme Court does not decide any longer as a court of second instance. We consider that the proposal to allow insurance measures can be submitted even when the case is in the court of second instance and this would be the way that such measure to be issued by individual judge or reporting judge, whereas the appeal against this decision be reviewed by a panel consisted of three professional judges. However, starting from the principle that no appeal is allowed against decisions of the court of second instance. Based on legal interpretation method of Article 310.1 of the LCP, which stipulates that "the decision of first instance on the insurance measure can be appealed within seven (7) days of its submission", we believe that against the second instance decision that insurance measure is ordered an appeal shall not be allowed. Whereas, as to that how much support will be given to this opinion, it is a matter of future how this will be decided by the case law of the second instance courts in these cases.

\section{Decision Making Procedure on the Insurance Measures}

In principle, lawsuit insurance measures cannot determine whether the insurance opponent was not given the opportunity to make a statement concerning such proposal, except in cases provided by law. ${ }^{45}$ Notification of insurance opponent and the opportunity to make an objection regarding the proposal for a insurance measure is a prerequisite for issuing the requested measure. The exception to this rule is that law only provides temporary measures but also in these instances, the insurance opponent can dispute the causes for the issuance of temporary measures, for which the court within 3 days is required to decide on these objections.

The Court firstly must review the proposal and its content and conclude that it is competent to handle the issue in the territorial jurisdiction point of view, to decide on the proposal. If it finds that, it is not competent then the proposal with submissions attached shall be forwarded to the competent court for decision-making. If it finds that it is competent, then a copy of the proposal together with the evidence that has been attached will be send to the insurance opponent, with the a notification that he/she can respond to in writing within 7 days of receipt of this proposal. ${ }^{46}$

Insurance opponent through response may challenge the proposed reasons for the issuance of the lawsuit

\footnotetext{
${ }^{43}$ Law on Courts of Kosovo no. 03/L-199, 22.07.2012, in force from 01.01.2013

${ }_{44}$ Rrustem Qehaja "Organizational structure of basic courts of Kosovo, Newsletter of the Chamber of Advocates of Kosovo "AVOKATURA" VITI: VIII, no. 15/2014, Pristina 2014, page 79

${ }^{45}$ LCP of Kosovo No.03/L-2006, 30.06.2008, Article 305.1

${ }^{46}$ LCP 2008, Article 305.2 and Ruling of the Municipal Court in Lipjan c.no.210/2012, 27.08.2012.
} 
insurance measure and in the response may attach necessary evidence, which challenge the facts of the proponent. In addition, insurance opponent in response to the proposal may not dispute the proposed measure and may propose to give the pledge instead as security measure and the court shall decide on this if proposed insurance satisfies this proposal.

After the expiry of the deadline for response, or after the opponent's response is received and, depending on its content and evidence, the court may approve the proposal and to order insurance measure or reject such proposal without conducting a hearing. However, if out of the content of the proposal and the claims of litigants, the court cannot establish its opinion on the measure, approval or rejection of the proposed measure, the same may appoint a hearing to review the reasonableness of the proposed measure.

When court conducts the hearing, to decide on the insurance measure, should be careful to not administer the evidence proposed by the litigants, as in the main hearing, but conduct this hearing only by superficially review them ${ }^{47}$ and so that the parties to present their views on the merits of the lawsuit and give their statement and evidence of the opposing party. So, the hearing on the insurance measure it is secondary type of hearing, which differs from the preparatory examination and the main trial. Therefore, special care should be paid in regard of not administering evidence as this should be only done during the trial and that there is a risk that the same evidence be twice administered (in the hearing on issuance of the insurance measure and in the main trial) and by doing so giving different meaning to the same evidence. If the proponent of the insurance measure based on the attached evidence has not made credible his/her subjective right, the court will reject the proposal on the insurance measure. ${ }^{48}$ Therefore, this is the first condition to allow the insurance measure without fulfillment of which the court cannot even talk about the fulfillment of other conditions.

\section{Conclusion}

Reform of the legal system of the Republic of Kosovo has conditioned the promulgation of the new laws, which are challenging the judiciary with respect to the implementation of the laws in civil law area. Lawsuit insurance constitutes only a small segment of the string of multiple dilemmas contained in the Law on Contested Procedure.

Therefore, we consider that in this regard we have to invest more efforts to increase the capacity of the judiciary in the direction of providing more continuous training of the current sitting judges through exchange of their experiences in different regions and increasing the number of judges especially those that handle civil law cases.

We think that such a step is very necessary and such a thing in itself constitutes a challenge to satisfy European integration standards.

\section{References}

Boris Pozniq, Law commentary on civil procedure, Belgrade 2009.

Ruling of the Municipal Court in Pristina C.no.1352/09, 22.09.2011

Ruling of the Municipal Court in Pristina C.no.464/12, 08.03.2012.

Ruling of the Municipal Court in Lipjan C.no.216/11, 22.08.2011.

Ruling of the Municipal Court in Lipjan C.no.210/2012, 27.08.2012.

Ruling of the Municipal Court in Lipjan, C.no.75/2011, 26.05.2011, confirmed by the Judgment of the District Court in Pristina AC.no.544/2011, 14.09.2011, and a Ruling of the Municipal Court in Pristina C.no.2203/12, 24.08.2012.

Ruling of the Municipal Court in Pristina C.no. 2602/12, 29.10.2012

Faik Brestovci, Civil Procedure Law I, Pristina 2006

Group of Authors, Law Commentary on Civil Procedure of Bosnia and Herzegovina Federation and Republic Serpska, Sarajevo, 2005

Iset Morina \& Selim Nikçi, Law Commentary on the Contested Procedure, Pristina, 2012

Constitution of the Republic of Kosovo (approved on 08.04.2008, entered into force on 15.06.2008)

Law on Contested Procedure, Official Gazete of RSFJ, Nr. 4/1977, 1977

Law on Executive Procedure, FRY Official Gazette no. 20/1978, 1978

Law no. 03/L-154 on Property and other Real Rights, 25.06.2009

Law No. 03 / L-006 on Contested Procedure, 30 June 2008, promulgated by Decree no. DL-045-2008, on 29.07.2008 by the President of

${ }^{47}$ Presentation by EULEX judges on Insurance Measures, 27.04.2012, page 5

${ }^{48}$ Ruling of the Municipal Court in Lipjan, C.no.75/2011, 26.05.2011, confirmed by the judgment of the District Court in Pristina Ac.no.544/2011, 14.09.2011, and Ruling of the Municipal Court in Pristina C.no.2203/12, 24.08.2012. 
the Republic of Kosovo, Dr. Fatmir Sejdiu and published in the Official Gazette of the Republic of Kosovo / Pristina: Year III / Nr.38 / 20, September 2008.

Law No. 04 / L-139 on Executive Procedure, 20 December 2012, promulgated by Decree no. DL-001-2013, on 03.01.2013 by the President of the Republic of Kosovo, Atifete Jahjaga and published in the Official Gazette of the Republic of Kosovo / No.3 / 31 January 2013, Pristina

Presentation by the EULEX judge on insurance measures, Pristina, 27.04.2012

Regulation of the Central Bank of Kosovo (CBK) on the Primary and Secondary Markets for issuance of Government Securities

Rrustem Qehaja "Organizational structure of basic courts in Kosovo, Newsletter of the Kosovo Chamber of Advocates "AVOKATURA" VITI: VIII, no. 15/2014, Pristina, 2014

Rrustem Qehaja "appeal against the judgment in the civil-contested procedure", Law life no. 1,March 2013, Tirana 2013 